\title{
Developing Students' Reading Comprehension by Using Literature Circle
}

\author{
Abstract \\ Kardi Nurhadi \\ Wiralodra University \\ Email.kardinurhadi@rocketmail.com
}

The objective of the research is to develop students'extensive reading by using Literature Circle. According to Daniels (2002) literature circle is an activity in which members meet to discuss and respond to a book that they are all reading. The writer used classroom action research as the research method. The steps of action research consist of planning, acting, observing and evaluating. The research participants took from the eleventh grade students of MAN Indramayu. Based on the learning activities from the first to second cycle, it showed there was an improvement of students extensive reading; it can be seen by the students progress of activity from the first to the second cycle, also the students showed a positive respond to the literature circle. From this research finding, it showed that story Literature Circle could develop the students' extensive reading.

Keywords: Literature Circle, extensive reading, action research.

\section{INTRODUCTION}

As stated in 2006 curriculum, the target of students in senior high school is to get informational level of litercy. In informational level, the students should be able to use English to get things done and use English for survival purposes (buying and selling, asking and giving permissions, making and cancelling appointmens, read and write simple texts, read popular science and etc.In terms of reading, the students should be able to read and comprehend any various text types in English for instance, narrative, procedure, recount and descriptive.

In terms of teaching reading, the research showed that some of students problem in reading. Klinger et.al (2007: 5) state that students have difficulties with decoded, fluency (reading words quickly and accurately), and vocabulary. Difficulty in any of these three areas will interfere with reading comprehension. In this case the students have limited in vocabulary, therefore they feel difficult to understand the reading texts. Mohamed et.al (2012: 280) also state that students have difficulty in locating the main ideas and supporting details when answering the literal comprehension questions.

Based on the writer pre-eliminary observation at the eleventh grade of students MAN Indramayu, the writer found that some problems related to the reading skills. Firstly, reading as an interactive process involving a text, a reader and a social context in which the activity of reading takes place. In reading 
comperehension, it is needed a time to do the interactive process, in fact, the students lack of time to do the interactive process. Secondly, reading also needs good mastery in vocabulary to comprehend the text. In fact, the students lack of vocabulary, therefore they feel difficult to understand what the text means. In reading," an individual constructs meaning through a transaction with written text that has been created by symbols that represent language. The transaction involves the reader's acting on or interpreting the text, and the interpretation is influenced by the reader's past experiences, language background and cultural framework, as well the reader's purpose for reading".

And then, in terms of reading comprehension, we should know the skills and strategies in reading, in order to get the purpose of comprehension. Grabe and stoller (2002: 15) also stated that skills represent linguistics processing abilities in their use and combinations (e.g word recognition and syntactic). While, strategies are often defined as a set of abilities under conscious control of the reader though this common definition is not likely to be true. The distinction between skills and strategies is not entirely clear precisely that is part of the nature of reading. In teaching of reading, the examples of reading skills for instance: word recognition, guessing the meaning, making reference, skimming, scanning, drawing inference, word in context and so on. In this case, based on the writer's observation, the reading skills of students are still low. It can be seen by result of reading test indicates that the score of reading achievement was not quite satisfied. The students feel difficult to understand and answering the questions from the passage; it is caused by the poor of reading skills. In fact, the teaching of reading in classroom does not present the reading skills. The teacher is just giving the instruction of test without any explanation how to answer the question by using reading skills.

Regarding the problems above, the writer would like to propose literature circle as the instructional strategy in teaching reading, especially reading comprehension of narrative texts. According to Daniels (2002: 40) a literature circle is an activity in which members meet to discuss and respond to a book that they are all reading . also it is explained by Cameron et al. (2012) literature circles are led mostly by students, while the teacher remains in the background and performs only basic control functions. Roles are usually assigned to members of the literature circle to allow the group to function productively and to help members remain focused on the chosen texts. By using this strategy, the writer assumed that, literature circle can help the students to comprehend and answer the reading texts easily. It is kind of group acticity where the students work and collaborate each other. For the reasons above, the writer would like to conduct the research entitled " The implementation of Literature Circle in Teaching Reading Comprehension of Narrative texs".

\section{LITERATURE REVIEW}

\subsection{The nature of reading}

Grabe and Stoller (2002: 9) explain that reading is the abilty to draw meaning from the printed page and interpret this information appropriately. It is a simple 
definiton of reading, it doesn't cover the component in reading, reading is an activity that involve many things such as skills and strategies. Both of skills and strategies are needed to get the purpose of reading. For example, when we pick up a newspaper, we usually read the front page with some combination of search processing, general reading comprehension and skimming.

Day and Bamford (1998: 12) define that reading is the construction of meaning from a printed or written message. The construction of meaning involves the reader connecting information from the written message with previous knowledge to arrive at meaning-at an understanding.

\subsection{The purpose of reading}

According to Grabe and Stoller (2002: 13), identified the seven purposes for reading, the purposes as follows:

a) Reading to search for simple information

b) Reading to skim quickly

c) Reading to learn from texts

d) Reading to get integrate information

e) Reading to write ( or search information needed for writing)

f) Reading to critique texts

g) Reading for general comprehension

\subsection{The teaching of reading}

In order to efficiently achieve and improve students' reading comprehension,three stages of classroom teaching should be applied to EFL reading instruction. Brown (200:101) explain that these stages are:

a) Pre-reading Stage

In this stage, teachers should arouse students' interests and motivation throughdiscussing pictures, titles and some key words. Students predict and talk about possibleideas of what the text might be about. Teachers are requested to establish a purpose ofreading within students and activate their prior knowledge and schemata as well.

b) While-reading Stage

As the name suggests, reading activities take place during the actual reading. Itfocuses on developing students' reading skills through answering multilevelcomprehension questions such as general understanding questions, detailedanswerquestions and high-order thinking questions.

c) Post-reading Stage:

The activities of this stage take place after the reading has been done. Here,teachers check students' understanding of what they have read, relate the text to theirpersonal experience and lives and relate and integrate reading to other language skills.For example, students can be asked to summarize in writing what they have read,discussed or debated over certain issues latent in the reading text. 


\subsection{Literature Circle}

A literature circle is an activity in which members meet to discuss and respond to a book that they are all reading (Daniels 2002). As Cameron et al. (2012) explain, literature circles are led mostly by students, while the teacher remains in the background and performs only basic control functions. Roles are usually assigned to members of the literature circle to allow the group to function productively and to help members remain focused on the chosen book. Examples of five individual roles are Discussion Director, Literary Luminary, Illustrator, Summarizer, and Vocabulary Enricher (Daniels and Steineke 2004). The Discussion Director's task, for example, could be to develop at least five questions about the text and then share these questions with the group. The Literary Luminary pinpoints important parts of the text for the group in order to stimulate thinking and elicit some interesting facts about the text. The Illustrator's job might be to draw pictures related to the reading and share the drawings with the group; the group members then speculate on the meaning of the pictures and connect them to their own ideas about the text. The Summarizer's role is to recall what happened in the reading and prepare a summary for the group, and the Vocabulary Enricher helps the group find and discuss new or difficult words.

\subsection{Benefits of literature circles}

Recent evidence demonstrates that literature circles positively impact student learningprocesses and language development. Muchof this impact is directed towards severalimportant areas for language learning,including the following.

a) Improved comprehension skills

Most important of all the benefits, literature circles help students developcomprehension skills that are essentialwhen reading a text. Literature circlessupport strategies such as visualizing, connecting, questioning, inferring, and analyzing that are vital to solid comprehension and lively conversation.

b) Enhance responsiblity and motivation

Another benefit of literature circles is helping students feel a sense of ownershipand responsibility. Student choice and socialinteraction easily integrate into literaturecircles, which support student motivationand can have a very powerful effect onachievement. Researchershave also found that when students work incollaborative groups they encourage eachother's efforts and that this leads to increasedmotivation and effort .

c) Expanded collaborative discussion

Reading specialists highlight discussion, student response, and collaboration - allaspects of literature circles - as importantfor providing a way for students to engage incritical thinking and reflection. When students learn a second language, collaborative discussions with peers often play a vital role in reinforcingcomprehension skills because the active involvement thattakes place entails speaking and listening tomany different perspectives, which deepenssecond language learners' understandings. 


\subsection{The instructional goals of literature circles}

Although instructional goals for literature circles may vary depending on the text andcontext, the goal of the unit is that students,through group activities and discussion, will be able to analyze and comprehend a text. At the end of this sample unit, students should be able to:

a) Demonstrate the ability to compare and contrast the personalities of the main characters;

b) Provide understanding of the plot and the setting of the story and the characters'actions;

c) Apply strategies to preview, comprehend, interpret, analyze, evaluate, and relateliterature to their own lives;

d) Understand literary conflicts;

e) Understand the idea of timelines, createconversations based on narratives, and usetransition signals to compare and contrast.

\section{METHOD}

Burns (1999: 3) defines that AR is part of a broad movement that has been going on in education generally for some time. It is related to the ideas of 'reflective practice' and 'the teacher as researcher'. AR involves taking a selfreflective, critical, and systematic approach to exploring your own teaching contexts. one of the main aims of AR is to identify 'problematic' situation or issue that the participants - who may include teachers, students, managers, administrators, or even parents - consider worth looking into more deeply and systematically.

Kemmis \& McTaggart (1988: 220) define that action research is 'self reflective enquiry' undertaken by participants in order to improve th rationality and justice of their own social or educational practices as well as their understanding of these practices and the situations in which these practices are carried out.

Based on the definition of action research above, the writer can sums up that action research is a systematic process that aims to solve the problem of teaching learning that has been identified. And then, one of the AR is to improve teaching - learning process through a set of step. In action research the teachers can choose the media, strategy and technique to improve their teaching and learning process.

According to Kemmis and McTaggart (1988: 250), who are major authors in this field, AR typically involves four broad phases in a cycle of research. The first cycle may become a continuing, or iterative, spiral of cycles which recur until the actionesearcher has achieved a satisfactory outcome and feels it is time to stop. The steps in action research are as follow: 
1) Planning

In this phase the teacher -researcher identify a problem or issue and develop a plan of action in order to bring about improvements in a specific area of the research context. This is a forward-looking phase where you consider: i) what kind of investigation is possible within the realities and constraints of your teaching situation; and ii) what potential improvements you think are possible.

2) Action

The plan is a carefully considered one which involves some deliberate interventions into your teaching situation that you put into action over an agreed period of time. The interventions are 'critically informed' as you question your assumptions about the current situation and plan new and alternative ways of doing things.

3) Observation

This phase involves you in observing systematically the effects of the action and documenting the context, actions and opinions of those involved. It is a data collection phase where you use 'open-eyed' and 'open-minded' tools to collect information about what is happening.

4) Reflection

At this point, you reflect on, evaluate and describe the effects of the action in order to make sense of what has happened and to understand the issue you have explored more clearly. You may decide to do further cycles of CAR to improve the situation even more, or to share the 'story' of your research with others as part of your ongoing professional development.

\section{FINDINGS AND DISCUSSION}

\subsection{Pre-action Class}

The students were given some treatments before implementing Classroom Action Research. They were: Observation, questioner, interview and pre-action test. Its aim is to know the condition of the students, classroom, also the teacher. Based on the data collected, it resulted some points. Generally, the condition was not ready to do teaching learning process. It effected that teaching learning process was not effective. It could be shown on the result of pre action test which class average score was only 65.14. Meanwhile, English KKM score is 75. It means that students were on the serious problem. They needed a special treatment. Also, the result of observation sheet said that many students less motivation of studying in the class. It may be caused by environment factor, such as teacher, media also the technique used. The data above were got from the research before implementing CAR. It was based on the Sugiono opinion in his book about the aim of research that methodological research basically is a scientific way to get the data for certain purposes. 


\subsection{Cycle 1}

In this cycle, all preparation were done. Such as; making lesson plan, time table, making teaching materials, preparing post-action test 1 form. It started implement Classroom Action Research which using Literature Circle in teaching students' reading comprehension at eleventh grade of MAN Indramayu. There were some treatments applied in this step. To know the result of first cycle, it was applied questionnaire sheet also the students were provided by post-action test 1 . This was to measure the students' achievement of first treatment. And the result said that there was an improvement of the students' achievement of understanding narrative text. It was supported by the data gotten. The students could improve their score on post-action test 1 . Based on the data that class average score was 75.43, which score was higher than before. It means that there was an improvement for about $15.79 \%$. To make sure about the effectiveness of the technique and to maximize the result, so it was decided to continue to the second cycle.

\subsection{Cycle 2}

In this cycle, the researcher did what he did in the first cycle. This steps is to strengthen the students' achievement of understanding narrative text by using Literature Circle. In this cycle, the students also were provided by post action test, which purpose to get the final result achievement. To show the result of the research, here are some graphs of students' achievement during implementing classroom action research in teaching narrative text by using Literature Circle. It stated that class average score before implementing CAR was 65.14, and after implementing CAR it gets improvement. The students' improvement of post action test 1 was 75.43 and 82.57 of post action test 2 . It indicates there was an improvement of students' achievement of English class. Its improvement was so significant, which in the first post-action test was $15.79 \%$ and the most significant improvement was $26.75 \%$ of the second post test.

Thus, the calculation of KKM improvement also occurs significant changes. Before implementing CAR, the students who achieve KKM standard was only $22.86 \%$. It indicated there was a serious problem of students' achievement in English class. Based on the data, after applying Literature Circle of teaching narrative text in the classroom, it resulted a significant improvement. It stated that $68.57 \%$ of the students who achieve KKM standard in the first cycle. And the second cycle, the students who could achieve KKM was 91.43\%. Based on the graph above, it states that there is an improvement of KKM percentage. It occurs after students are treated by teaching narrative text using Literature Circle. It means that using story map in teaching narrative text was an effective way to improve the students' English score, especially in reading skill. Based on the theory of Nazir in his book about the purpose the research. The research was used to give the ideas of empirical evidence about using Literature Circle strategy on improving the students' understanding of narrative text. It was proved by the data 
got that Literature Circle could improve the students understanding of narrative text.

\section{CONCLUSION AND SUGGESTION 5.1.1. CONCLUSION}

After implementing Classroom Action Research at the eleventh grade students of MAN Indramayu and based on the result of any tests, it could be summarized that there was a significant difference before and after implementing Literature Circle strategy in teaching narrative text. It means that using literaure circle in teaching reading is helpful, especially in improving students' reading comprehension of narrative text. It can be shown from the result of pre-action test and some post-action test.

Furthermore the students' improvement of reading comprehension of narrative text can be seen clearly in the students' improvement score of their achievement in pre-action test and two post-action tests. The result of pre-action and post-action test shown the significant improvement. The average score of preaction test was 65.14 . it means there were only $22.86 \%$ of the whole students could pass the KKM. The average score of post-action test 1 was 75.43 it proved that $68.57 \%$ students could passed KKM. the average score of post-action test was 82.57. Then, it was obtained that the percentage of students who could get the score above the KKM in post-test 2 was $91.43 \%$. It can be concluded that teaching narrative text by using Literature Circle strategy, the students' reading comprehension of narrative text can be effectively improved.

\subsubsection{SUGGESTION}

Based on the conclusion above, it can be delivered some suggestions to be paid more attention in teaching and learning process go to:

1) Teachers should prepare and select appropriate method and materials to produce the effective teaching learning process. Also, the teacher $\mathrm{s}$ should determine the target of the teaching which must be achieved. It was important for teachers should pay more attention to students' activity during the teaching learning process in order to achieve the goal of study. The last, the teachers should be able to create the teaching learning process enjoyable, such as selecting interesting text or new teaching media.

2) Students should know some methods which may be used in learning to improve their understanding.

3) Other researchers may use this research result as a guideline to complete the project in similar problem of the students.

4) Readers can take notes from this research for certain academic purposes. 


\section{REFERENCES}

Anderson, M.(1997). Text Types in English 2. Australia: MacMillan

Brown,H.D.(2000). Teaching by Principles: Second Edition. California.Longman.

Burns, A. (1999). Collaborative action research for English language teachers. Cambridge: Cambridge University Press.

Cameron, S., M. Murray, K. Hull, and J. Cameron. (2012). Engaging fluent readers using literature circles. Literacy Learning: The Middle Years 20 (1): i-viii.

Celce -Murcia, M.(2010). Teaching English as a Second or Foreign Language: Third Edition. USA. Heinle \& Heinle Press

Cresswell, J.W.(1994). Research Design Qualitative and Quantitative Approaches. USA. Sage Publications

Daniels, H.( 2002). Literature circles: Voice and choice in book clubs and reading groups. 2nd ed. Portland, ME: Stenhouse.

Daniels, H., and N. Steineke. (2004). Mini-lessons for literature circles. Portsmouth, NH: Heinemann.

Day,Richard and Bamford,J.(1998). Extensive Reading in the Second Language Classroom.USA: Cambridge University Press

Derewianka,B.(1990). Exploring How Texts work. Australia: Primary English Teaching Association

Egbert, J and Elhess, M. (2015). Literature Circle as Support for Language Development. americanenglish.state.gov/english-teaching-forum

Grabe,W and Stoller,F. 2002.Teaching and Researching Reading. London: Longman.

Harmer,J.(1983). The Practice of English Language Teaching. New York: Longman Inc.

Kemmis, S. \& McTaggart, R. (1988). The Action Research Planner. Melbourne: Deakin University Press.

Klinger, et.al. (2007). Teaching Reading Comprehension to the Students with Learning Difficulties. New York: The Guilford Press. 
Kardi Nurhadi Developing Students' Reading Comprehension by Using Literature Circle

Mohamed, A. R. Et.al (2012). The potency of 'READS' to Inform Students' Reading Ability. RELC Journal 